\title{
Integrated Nutrient Management in Groundnut at Coastal Zone of Karnataka, India
}

\author{
R. Nagaraj ${ }^{1 *}$, M. Hanumanthappa ${ }^{2}$ and K. V. Sudhir Kamath ${ }^{3}$
}

${ }^{1}$ (Agronomy), College of Agriculture, UAHS, Shivamogga, Karnataka, India

${ }^{2}$ (Hort.), College of Horticulture, Mudigere, Chickamagluru, Karnataka, India

${ }^{3}$ Department of Agronomy, ZAHRS, Brahmavar, Udupi, Karnataka, India

*Corresponding author

\section{A B S T R A C T}

\begin{tabular}{|l|}
\hline K e y w or d s \\
Yield, Groundnut, \\
Vermicompost, \\
Poultry manure, \\
Eupatorium, POP \\
\hline Article Info \\
\hline $\begin{array}{l}\text { Accepted: } \\
\text { 18 May 2018 } \\
\text { Available Online: } \\
\text { 10 June } 2018\end{array}$ \\
\hline
\end{tabular}

\section{Introduction}

India requires around 20.3 million tonnes of edible oil. It is essential to enhance the productivity of prominent crops of the country like paddy, wheat, pulses and groundnut through location- specific nutrient management practices. To augment major food crops production, Food and Agriculture Organization (FAO) conceptualized the idea of plant nutrients in a crop and cropping system for better resource use. It is not only a reliable way of obtaining fairly higher yields with substantial fertilizer economy, but also a

\begin{abstract}
Pod and haulm yield was significantly superior in POP +50 per cent RDN through poultry manure (2272 and $2900 \mathrm{~kg} \mathrm{ha}^{-1}$, respectively) followed by POP +50 per cent RDN through vermicompost (2162 and $2771 \mathrm{~kg} \mathrm{ha}^{-1}$, respectively). Treatments receiving POP + 50 per cent RDN through poultry manure and $\mathrm{POP}+50$ per cent RDN through vermicompost resulted in significantly more nitrogen, $\mathrm{P}_{2} \mathrm{O}_{5}$ and $\mathrm{K}_{2} \mathrm{O}$ uptake $(99.05,28.20$, 32.93 and $94.15,27.00,29.28 \mathrm{~kg} \mathrm{ha}^{-1}$, respectively). Significant influence of treatments on in availability which was higher in POP +50 per cent RDN through eupatorium $\left(390.16 \mathrm{~kg} \mathrm{ha}^{-1}\right)$, followed by POP +50 per cent RDN through gliricidia (388.66) and POP +50 per cent RDN through goat manure $\left(384.97 \mathrm{~kg} \mathrm{ha}^{-1}\right)$. Significantly higher availability of phosphorus was found in POP +50 per cent RDN through poultry manure $(85.26 \mathrm{~kg} \mathrm{ha}$ $\left.{ }^{1}\right)$, followed by POP +25 per cent RDN through goat manure $\left(79.10 \mathrm{~kg} \mathrm{ha}^{-1}\right)$. Application of recommended dose of nutrients +50 per cent RDN through eupatorium resulted in higher available $\mathrm{K}_{2} \mathrm{O}\left(152.93 \mathrm{~kg} \mathrm{ha}^{-1}\right)$ as compared to other treatments.
\end{abstract}

concept that is ecologically sound leading to sustainable agriculture. None of the sources of nutrient alone can meet the total plant nutrients. Integration of from chemical, organic and biological sources of nutrients is the most efficient way to supply plant nutrients for sustained crop productivity and improved of soil fertility (Singh and Singh, 2002). Among problematic soils, acid soils less availability of nutrients $(\mathrm{N}, \mathrm{P}, \mathrm{Ca}, \mathrm{S}$, and $\mathrm{B})$ besides inadequate organic matter. Paddy and groundnut being, exhaustive crops, removes large amount of macro and micro nutrients from soil. None of the sources of 
nutrient alone can meet the total plant nutrients. Integration of from chemical, organic and biological sources of nutrients is the most efficient way to supply plant nutrients for sustained crop productivity and improved of soil fertility

It is therefore necessary to judiciously manage the inflow of organic sources of nutrients, and their integration with fertilizers, biofertilizers and organic manure. Application of organic materials along with inorganic fertilizers leads to increased productivity of the system and sustained soil health for a longer period (Gawai and Pawar, 2006). Due to escalation of fertilizer prices and associated environment problem the crisis has necessitated in search for alternative sources of manures for integrated nutrient management, which includes organic manures, biofertilizers and inclusion of legume (groundnut) to sustain the cereal based cropping system.

\section{Materials and Methods}

A field experiment was conducted during rabi season of 2015 at Zonal Agricultural and Horticultural Research Station, Brahmavar, Udupi district, Karnataka, to study the of integrated nutrient management in groundnut. The experimental site is situated between $74^{\circ}$ $45^{\prime}$ to $74^{0} 46^{\prime}$ East longitude and $13^{\circ} 24^{\prime} 45^{\prime}$ ', to $13^{\circ} 25^{\prime} 30^{\prime}$ ' North latitude and an altitude of 10 meters above mean sea level. Soil type is sandy loam in texture and $\mathrm{pH}$ was acidic (4.78). The soil was medium in available nitrogen (362.84 $\left.\mathrm{kg} \mathrm{ha}^{-1}\right)$, high in available phosphorus (56.28 kg ha ${ }^{-1}$ ) and medium in available potassium $\left(113.61 \mathrm{~kg} \mathrm{ha}^{-1}\right)$. The organic carbon content was high $(1.32 \%)$ in range. TMV-2 a popular variety was sown in January with a spacing of $30 \mathrm{~cm} \mathrm{X} 10 \mathrm{~cm}$ in paddy fallow. Experiment included twelve treatments consisted of $\mathrm{T}_{1}-$ Package of practice (POP- FYM $10 \mathrm{t}+25: 50: 25 \mathrm{~kg}$ $\mathrm{N}: \mathrm{P}_{2} \mathrm{O}_{5}: \mathrm{K}_{2} \mathrm{O}$ ha $\left.^{-1}\right), \mathrm{T}_{2^{-}} \mathrm{POP}+25$ per cent
RDN through eupatorium, $\mathrm{T}_{3}-\mathrm{POP}+25$ per cent RDN through gliricidia, $\mathrm{T}_{4}-\mathrm{POP}+25$ per cent RDN through vermicompost, $\mathrm{T}_{5^{-}} \mathrm{POP}+$ 25 per cent RDN through poultry manure, $\mathrm{T}_{6}$ $\mathrm{POP}+25$ per cent RDN through goat manure, $\mathrm{T}_{7-} \mathrm{POP}+50$ per cent RDN through eupatorium, $\mathrm{T}_{8}-\mathrm{POP}+50$ per cent RDN through gliricidia, $\mathrm{T}_{9}-\mathrm{POP}+50$ per cent $\mathrm{RDN}$ through vermicompost, $\mathrm{T}_{10^{-}} \mathrm{POP}+50$ per cent RDN through poultry manure, $\mathrm{T}_{11}$ - POP +50 per cent $\mathrm{RDN}$ through goat manure and $\mathrm{T}_{12^{-}}$ Control were laid out in Randomized Complete Block Design (RCBD) with three replications. All organics were applied 25 days before transplanting of paddy. Yield (biological and economical) was recorded from individual plots at harvest and converted to $\mathrm{kg} / \mathrm{ha}$. Composite soil sample were used to assess soil nutrient status. Standard statistical methods were used for comparing the treatment means.

\section{Results and Discussion}

\section{Yield of groundnut}

Pod yield was significantly superior in POP + 50 per cent RDN through poultry manure $\left(2272 \mathrm{~kg} \mathrm{ha}^{-1}\right)$ followed by POP +50 per cent RDN through vermicompost (2162 $\mathrm{kg} \mathrm{ha}^{-1}$ ) and $\mathrm{POP}+50$ per cent RDN through goat manure $\left(2018 \mathrm{~kg} \mathrm{ha}^{-1}\right)$. The former treatment $\left(\mathrm{T}_{10}\right)$, followed by POP +50 per cent RDN through vermicompost $\mathrm{POP}+50$ per cent RDN through goat manure and $\mathrm{POP}+50$ per cent RDN through gliricidia resulted in significantly higher haulm yield (2900, 2771, 2653 and $2598 \mathrm{~kg} \mathrm{ha}^{-1}$, respectively) (Table 1). Higher economical and biological yields in poultry manure might be due to ammonium-N $(\mathrm{NH} 4-\mathrm{N})$ is a significant part of total $\mathrm{N}$ in poultry manure, which additionally contains uric acid. Uric acid metabolizes rapidly to $\mathrm{NH}_{4}-\mathrm{N}$ in most soils, and the net result of the high $\mathrm{NH}_{4}-\mathrm{N}$ and uric acid contents in poultry waste is that a large percentage of $\mathrm{N}$ can be 
converted to nitrate- $\mathrm{N}\left(\mathrm{NO}_{3}-\mathrm{N}\right)$ within a few weeks. Poultry manure improves the number of pods per plant, pod yield and haulm yield in groundnut (Veeramani et al., 2012). The increase in pod yield in vermicompost treatment may be attributed to the reason that organic manure along with FYM and inorganic nutrients possibly increased the concentration of $\mathrm{N}, \mathrm{P}$ and $\mathrm{K}$ ions of soil solution and ultimately affected the formation of more nodules, vigorous root development, better $\mathrm{N}$ fixation and better development of plant growth leading to higher photosynthetic activity and translocation of photosynthates to the sink which in turn resulted in better development of yield attributes and finally in higher pod yield. The findings closely followed the results of Badole et al., (2001) and Thakare et al., (2003).

\section{Uptake of nutrients}

Treatments receiving POP +50 per cent $\mathrm{RDN}$ through poultry manure, $\mathrm{POP}+50$ per cent RDN through vermicompost and POP +50 per cent RDN through goat manure resulted in significantly more nitrogen uptake (99.05, 94.15 and $88.47 \mathrm{~kg} \mathrm{ha}^{-1}$, respectively). The total uptake of phosphorus in POP +50 per cent RDN through poultry manure recorded significantly higher value of $28.20 \mathrm{~kg} \mathrm{ha}^{-1}$ followed by $\mathrm{POP}+50$ per cent RDN through vermicompost and $\mathrm{POP}+50$ per cent RDN through goat manure (27.00 and $25.15 \mathrm{~kg} \mathrm{ha}^{-1}$, respectively). The data showed that the former treatment $\left(\mathrm{T}_{10}\right)$ recorded significantly higher total uptake of potassium (32.93 $\left.\mathrm{kg} \mathrm{ha}^{-1}\right)$ which was on par with POP +50 per cent RDN through vermicompost and POP +50 per cent RDN through eupatorium treatments (29.28 and $29.20 \mathrm{~kg} \mathrm{ha}^{-1}$, respectively) (Table 2). The uptake of nutrients was increased with the application of graded combination of vermicompost and poultry manure. Such increases in nitrogen and phosphorus contents and uptake in kernel and haulm with the application vermicompost and poultry manure might be due to enhanced supply of plant nutrients by direct addition through nitrogen fixation and solubilisation of native phosphorus content of soil and also by increasing nutrient use efficiency and better absorption and utilization of nutrient in balanced form (Choudhary et al., 2011). Another factor contributing to more nutrient uptake with poultry manure might be due to presence of high phosphorus content and increased availability of native soil phosphorus. The results corroborated the finding of Bulu et al., (2016) in groundnut production in which they reported that organic manure, especially poultry manure and goat manure could increase yield of crops when compared with other sources of manure. Further, Chromolaena odorata contain N, P, and $\mathrm{K}$ which improve the soil cation exchange capability, due to increased soil organic colloids. Soil organic colloids can be either humic or other organic compounds. The increasing of organic colloids will extend the area of nutrients absorption in the soil. It can decrease the loss of nutrients due to leaching that takes place in the soil. It has been described that humic acid has a negative surface originating from the dissociation of carboxylate groups and its phenolate (Jamilah, 2006).

\section{Availability of nutrients}

The data revealed that significant influence of treatments on nitrogen availability which was higher in $\mathrm{POP}+50$ per cent RDN through eupatorium (390.16 kg ha-1), followed by POP +50 per cent RDN through gliricidia (388.66) and POP +50 per cent RDN through goat manure $\left(384.97 \mathrm{~kg} \mathrm{ha}^{-1}\right)$. Significantly higher availability of phosphorus was found in POP + 50 per cent RDN through poultry manure $\left(85.26 \mathrm{~kg} \mathrm{ha}^{-1}\right)$, followed by POP +25 per cent RDN through goat manure $(79.10 \mathrm{~kg}$ ha $\left.{ }^{1}\right)$. 
Table.1 Pod yield, kernel yield, haulm yield and harvest index of groundnut as influenced by integrated nutrient management

\begin{tabular}{|c|c|c|c|c|}
\hline Treatments & $\begin{array}{l}\text { Pod yield } \\
\left(\mathrm{kg} \mathrm{ha}^{-1}\right)\end{array}$ & $\begin{array}{l}\text { Kernel yield } \\
\left(\mathrm{kg} \mathrm{ha}^{-1}\right)\end{array}$ & $\begin{array}{l}\text { Haulm yield } \\
\left(\mathrm{kg} \mathrm{ha}^{-1}\right)\end{array}$ & Harvest index \\
\hline $\mathrm{T}_{1}-\mathrm{POP}\left(\mathrm{FYM} 10 \mathrm{t}+25: 50: 25 \mathrm{~kg} \mathrm{~N}: \mathrm{P}_{2} \mathrm{O}_{5}: \mathrm{K}_{2} \mathrm{Oha}^{-1}\right)$ & 1725 & 1163 & 2223 & 0.439 \\
\hline $\mathrm{T}_{2}-\mathrm{POP}+25 \% \mathrm{RDN}$ through eupatorium & 1683 & 1199 & 2262 & 0.426 \\
\hline $\mathrm{T}_{3}-\mathrm{POP}+25 \% \mathrm{RDN}$ through gliricidia & 1732 & 1214 & 2345 & 0.424 \\
\hline $\mathrm{T}_{4}-\mathrm{POP}+25 \% \mathrm{RDN}$ through vermicompost & 1809 & 1269 & 2456 & 0.424 \\
\hline $\mathrm{T}_{5}-\mathrm{POP}+25 \% \mathrm{RDN}$ through poultry manure & 1913 & 1341 & 2501 & 0.434 \\
\hline $\mathrm{T}_{6}-\mathrm{POP}+25 \% \mathrm{RDN}$ through goat manure & 1821 & 1262 & 2367 & 0.436 \\
\hline $\mathrm{T}_{7}-\mathrm{POP}+50 \%$ RDN through eupatorium & 1832 & 1325 & 2435 & 0.428 \\
\hline $\mathrm{T}_{8}-\mathrm{POP}+50 \% \mathrm{RDN}$ through gliricidia & 1932 & 1366 & 2598 & 0.427 \\
\hline $\mathrm{T}_{9}-\mathrm{POP}+50 \% \mathrm{RDN}$ through vermicompost & 2162 & 1574 & 2771 & 0.438 \\
\hline $\mathrm{T}_{10}-\mathrm{POP}+50 \% \mathrm{RDN}$ through poultry manure & 2272 & 1665 & 2900 & 0.439 \\
\hline $\mathrm{T}_{11}-\mathrm{POP}+50 \% \mathrm{RDN}$ through goat manure & 2018 & 1458 & 2653 & 0.432 \\
\hline $\mathrm{T}_{12}-$ Control & 810 & 319 & 1195 & 0.405 \\
\hline S. Em \pm & 105.12 & 90.89 & 123.34 & 0.019 \\
\hline $\mathrm{CD}(\mathrm{P}=0.05)$ & 308 & 267 & 362 & NS \\
\hline
\end{tabular}

POP- Package of practice; RDN- Recommended dose of nitrogen 
Table.2 Nitrogen, Phosphorus $\left(\mathrm{P}_{2} \mathrm{O}_{5}\right)$ and Potassium $\left(\mathrm{K}_{2} \mathrm{O}\right)$ uptake $\left(\mathrm{kg} \mathrm{ha}^{-1}\right)$ of groundnut as influenced by integrated nutrient management

\begin{tabular}{|c|c|c|c|}
\hline Treatments & Nitrogen & $\mathbf{P}_{2} \mathrm{O}_{5}$ & $\mathbf{K}_{2} \mathbf{O}$ \\
\hline $\mathrm{T}_{1}-\mathrm{POP}\left(\mathrm{FYM} 10 \mathrm{t}+25: 50: 25 \mathrm{~kg} \mathrm{~N}: \mathrm{P}_{2} \mathrm{O}_{5}: \mathrm{K}_{2} \mathrm{O} \mathrm{ha}^{-1}\right)$ & 72.08 & 18.50 & 26.97 \\
\hline $\mathrm{T}_{2}-\mathrm{POP}+25 \%$ RDN through eupatorium & 73.91 & 20.88 & 26.48 \\
\hline $\mathrm{T}_{3}-\mathrm{POP}+25 \% \mathrm{RDN}$ through gliricidia & 75.27 & 21.27 & 25.25 \\
\hline $\mathrm{T}_{4}-\mathrm{POP}+25 \% \mathrm{RDN}$ through vermicompost & 78.81 & 22.35 & 26.13 \\
\hline $\mathrm{T}_{5}-\mathrm{POP}+25 \% \mathrm{RDN}$ through poultry manure & 82.04 & 23.29 & 28.89 \\
\hline $\mathrm{T}_{6}-\mathrm{POP}+25 \% \mathrm{RDN}$ through goat manure & 77.38 & 22.05 & 26.24 \\
\hline $\mathrm{T}_{7}-\mathrm{POP}+50 \% \mathrm{RDN}$ through eupatorium & 80.62 & 22.74 & 29.20 \\
\hline $\mathrm{T}_{8}-\mathrm{POP}+50 \% \mathrm{RDN}$ through gliricidia & 83.99 & 23.81 & 25.56 \\
\hline $\mathrm{T}_{9}-\mathrm{POP}+50 \% \mathrm{RDN}$ through vermicompost & 94.15 & 27.00 & 29.28 \\
\hline $\mathrm{T}_{10}-\mathrm{POP}+50 \% \mathrm{RDN}$ through poultry manure & 99.05 & 28.20 & 32.93 \\
\hline $\mathrm{T}_{11}-\mathrm{POP}+50 \% \mathrm{RDN}$ through goat manure & 88.47 & 25.15 & 28.58 \\
\hline $\mathbf{T}_{12}$ - Control & 31.78 & 6.72 & 6.97 \\
\hline S. Em \pm & 4.72 & 1.91 & 1.95 \\
\hline $\mathrm{CD}(\mathrm{P}=\mathbf{0 . 0 5})$ & 13.87 & 5.61 & 5.73 \\
\hline
\end{tabular}

POP- Package of practice; RDN- Recommended dose of nitrogen 
Table.3 Nutrient status of soil after harvest of groundnut as influenced by integrated nutrient management

\begin{tabular}{|c|c|c|c|}
\hline Treatments & $\begin{array}{l}\text { Available nitrogen } \\
\qquad\left(\mathrm{kg} \mathrm{ha}^{-1}\right)\end{array}$ & $\begin{array}{c}\text { A vailable } \mathrm{P}_{2} \mathrm{O}_{5} \\
\left(\mathrm{~kg} \mathrm{ha}^{-1}\right)\end{array}$ & $\begin{array}{l}\text { Available } \mathrm{K}_{2} \mathrm{O} \\
\qquad\left(\mathrm{kg} \mathrm{ha}^{-1}\right)\end{array}$ \\
\hline $\mathrm{T}_{1}-\mathrm{POP}\left(\mathrm{FYM} 10 \mathrm{t}+25: 50: 25 \mathrm{~kg} \mathrm{~N}: \mathrm{P}_{2} \mathrm{O}_{5}: \mathrm{K}_{2} \mathrm{O} \mathrm{ha}^{-1}\right)$ & 376.20 & 65.00 & 134.16 \\
\hline $\mathrm{T}_{2}-\mathrm{POP}+25 \% \mathrm{RDN}$ through eupatorium & 384.17 & 67.10 & 136.10 \\
\hline $\mathrm{T}_{3}-\mathrm{POP}+25 \% \mathrm{RDN}$ through gliricidia & 383.01 & 62.00 & 138.17 \\
\hline $\mathrm{T}_{4}-\mathrm{POP}+25 \%$ RDN through vermicompost & 381.54 & 64.90 & 129.53 \\
\hline $\mathrm{T}_{5}-\mathrm{POP}+25 \% \mathrm{RDN}$ through poultry manure & 379.90 & 68.43 & 132.42 \\
\hline $\mathrm{T}_{6}-\mathrm{POP}+25 \% \mathrm{RDN}$ through goat manure & 381.91 & 79.10 & 135.67 \\
\hline $\mathrm{T}_{7}-\mathrm{POP}+50 \% \mathrm{RDN}$ through eupatorium & 390.16 & 70.16 & 152.93 \\
\hline $\mathrm{T}_{8}-\mathrm{POP}+50 \% \mathrm{RDN}$ through gliricidia & 388.66 & 61.80 & 142.80 \\
\hline $\mathrm{T}_{9}-\mathrm{POP}+50 \%$ RDN through vermicompost & 381.01 & 64.44 & 143.16 \\
\hline $\mathrm{T}_{10}-\mathrm{POP}+50 \% \mathrm{RDN}$ through poultry manure & 378.21 & 69.15 & 145.95 \\
\hline $\mathrm{T}_{11}-\mathrm{POP}+50 \% \mathrm{RDN}$ through goat manure & 384.97 & 85.26 & 147.81 \\
\hline $\mathbf{T}_{12}-$ Control & 318.10 & 39.14 & 95.67 \\
\hline S. Em \pm & 18.95 & 12.52 & 15.04 \\
\hline $\mathrm{CD}(\mathrm{P}=0.05)$ & 55.65 & 36.79 & 44.49 \\
\hline
\end{tabular}

POP- Package of practice; RDN- Recommended dose of nitrogen 
Application of recommended dose of nutrients +50 per cent RDN through eupatorium resulted in higher available $\mathrm{K}_{2} \mathrm{O}$ (152.93 kg ha ${ }^{-1}$ ) as compared to other treatments (Table 3). The increase in soil available $\mathrm{N}, \mathrm{P}$ and $\mathrm{K}$ could be attributed to greater biological nitrogen fixation with adequate $\mathrm{P}$ supply. The nodulation of legume crop fixes atmospheric $\mathrm{N}$ and $\mathrm{N}$ content in soil increases. The status of soil $\mathrm{P}$ improved firstly due to direct application of $\mathrm{P}$ to soil, and secondly through organic acids released by legume roots capable of solubilizing soil $\mathrm{P}$. The results are in close conformity with Dadhich et al., (2011). The increased $\mathrm{N}$ was due to the high $\mathrm{N}$ content in goat manure (Pannerselvam et al., 1999), slow release of nitrogen and improved nitrogen fixation by soil microbes (Goyal et al., 1992). Application of goat manure increased $\mathrm{K}$ availability as a consequence of releases of potassium from the added goat manure and solubilization of potassium from minerals (Jagannathan et al., 1990).

\section{References}

Bulu, Y. I., Kekere, O. and Olabokunde, B. G., 2016. Soil chemical properties and interactive effect of livestock manure and variety on growth, yield, seed nutritional and proximate compositions of groundnut (Arachis hypogaea L.). International Journal of Plant \& Soil Science, 11(4): 1-8.

Choudhary, S. K., Jat, M. K., Sharma S.R. and Singh, P., 2011. Effect of INM on soil nutrient and yield in groundnut field of semi-arid area of Rajasthan. Legume Res., 34(4): 283 - 287.

Dadhich, S. K, Somani, L. L. and Shilpkar, D., 2011. Effect of integrated use of fertilizer P, FYM and biofertilizers on the soil properties and productivity of soybean-wheat crop sequence. Journal of Advances in Developmental Research, 2(1): 42-46.

Gawai, P. P. AND Pawar, V. P., 2006. Integrated nutrient management in sorghum (Sorghum bicolor)-chickpea (Cicer arietinum) cropping sequence under irrigated conditions. Indian $\mathrm{J}$. Agron., 51: 17-20.

Jagannathan, S., Mayalagu, K., Peermohamed, M. and Gopalswamy, A., 1990. Residual effect of different amendments and $\mathrm{N}$ levels applied to the preceding rice crop on the soil properties and yield of succeeding greengram crop. Madras Agric. J., 77(7 \& 8): 273- 277.

Jamilah, 2006. Substitution $\mathrm{N}$ fertilizer by green manure to maize, given rock phosphate and vesicular-arbuscular mycorrhiza. Academica, 10: 1-7.

Pannerselvam, S., Christopher, A. Lourduraj, Balasubramaniam, N. and Velayutham, A., 1999. Influence of season, organic manures, fertilizers and weed management practices on the yield of soybean. Madras Agric. J., 86(4-6): 260 - 263.

Singh, B. and Singh, Y., 2002. Concepts in nutrient management. In: Recent Advances in Agronomy. Indian Soc. Agron., New Delhi. Pp. 92-109.

Thakare, G. V., Ulemale, R. B., Shivankar, R. S. and Dahiphale, A. V., 2003. Mophalogical indices \& yield attributes as influenced by integrated nutrient management in summer groundnut. Ann. Plant Physiol., 17(1): 1-5.

Veeramani, P., Subrahmaniyan, K. and Ganesaraja, V., 2012. Organic manure management on groundnut; A review. Wudpecker J. Agric. Res., 1(7): 238243. 


\section{How to cite this article:}

Nagaraj R., M. Hanumanthappa and Sudhir Kamath K. V. 2018. Integrated Nutrient Management in Groundnut at Coastal Zone of Karnataka. Int.J.Curr.Microbiol.App.Sci. 7(06):

1737-1744. doi: https://doi.org/10.20546/ijcmas.2018.706.206 